Table 1. Common Presentations of Congenital Rubella Syndrome ${ }^{4}$

\begin{tabular}{ll}
\hline Systems & Findings \\
\hline Ophthalmology & $\begin{array}{l}\text { Cataracts, congenital glaucoma, } \\
\text { microphthalmos, pigmentation retinopathy }\end{array}$ \\
\hline Cardiac & $\begin{array}{l}\text { Patent ductus arteriosus, peripheral pulmonary } \\
\text { artery stenosis }\end{array}$ \\
\hline Hematology & $\begin{array}{l}\text { Thrombocytopenia, hemolytic anemia, } \\
\text { petechiae/purpura, dermal erythropoiesis } \\
\text { causing blueberry muffin rash }\end{array}$ \\
\hline Neurology & $\begin{array}{l}\text { Behavioral disorders, meningoencephalitis, } \\
\text { microcephaly, mental retardation, autism, }\end{array}$ \\
\hline Hearing & Sensorineural hearing loss \\
\hline
\end{tabular}

(ie, unaware of her pregnancy at that time). The mother recalled febrile illness with rash, conjunctival infection about a week prior to the vaccine administration. The infant's rubella virus genotypic test by public health laboratory identified wild-type virus, indicating that CRS was acquired from the initial maternal viral infection and was not related to the maternal rubella vaccine.

Importantly, CRS, being a multisystem disease, requires a multidisciplinary team approach to improve patient outcomes (Table 1). The treatment of patients with CRS is largely supportive, though it has incredible implications for long-term neurodevelopmental outcomes. The opportunity for early intervention for psychiatric pathology has long-term implications on overall patient outcome. $^{3}$

Obstetricians and pediatricians should be aware of the unique scenario, as mentioned. If the maternal infection is confirmed during pregnancy, the further risk of CRS to fetus needs to be discussed with family. Congenital defects occur in up to $85 \%$ of fetuses if maternal infection occurs during first 12 weeks of gestation, $50 \%$ if infection occurs during the first 13 to 16 weeks of gestation, and $25 \%$ if the infection occurs during the end of second trimester. Additionally, in case of inadvertent rubella vaccine administration during pregnancy or if the pregnancy occurs within 28 days of immunization, the patient should be counseled on the theoretical risks to the fetus although the risk is $0.2 \%$, which is considerably lower than the risk with wild rubella virus. ${ }^{4}$

A CRS diagnosis has important implications for infection control, necessitating early identification in the neonatal period. Infants with CRS can continue to shed the virus in urine and nasopharyngeal secretions for up to 1 year. Interestingly, the virus has been reported to be shed for up to 3 years in infants with a high titer from lens aspirate. ${ }^{5}$ Contact isolation is indicated for children with proven or suspected congenital rubella until they are at least 1 year of age, unless 2 cultures of clinical specimens (throat swab and urine specimen) obtained 1 month apart after 3 months of age are negative for rubella virus. Hand hygiene cannot be overemphasized in such a situation in reducing transmission from the urine of children with CRS. Given the comorbidities of CRS, these infants will likely need frequent clinic visits to various subspecialists as well, increasing the chances of exposure to relatively susceptible populations. The appropriate isolation precautions can only be instituted if the CRS diagnosis has been considered and confirmed. CRS is a reportable disease, and all cases should be reported through local or state health departments.

Physicians need a low threshold for investigating the possibility of CRS in neonates in a clinically relevant setting, not only for the accurate diagnosis but also for the direction of appropriate supportive care in timely manner due to multisystem morbidities. Appropriate infection control strategies should be ensured in public settings until these patients become noncontagious to limit the spread of the virus in the rest of the susceptible community.

Acknowledgments. We would like to thank the parents of the patient to allow us to publish her case.

Financial support. No financial support was provided relevant to this article.

Conflicts of interest. All authors report no conflicts of interest relevant to this article.

\section{References}

1. Al Hamoud R, Murphy JR, Perez N. Imported congenital rubella syndrome, United States, 2017. Emerg Infect Dis 2018;24:800-801.

2. Shukla S, Maraqa NF. Congenital Rubella. NCBI website, StatPearls. https:// www.ncbi.nlm.nih.gov/books/NBK507879/2019. Published 2019. Accessed July 15, 2019.

3. Chauhan N, Sen MS, Jhanda S, Grover S. Psychiatric manifestations of congenital rubella syndrome: a case report and review of literature. J Pediatr Neurosci 2016;11:137-139.

4. Rubella. In: Kimberlin DW, Brady MT, Jackson MA, Long SS, editors. Red Book: Report of the Committee on Pediatric Infectious Diseases Report of the Committee on Pediatric Infectious Diseases, 31st ed. Itasca, IL: American Academy of Pediatrics; 2018:707-710.

5. Menser MA, Harley JD, Hertzberg R, Dorman DC, Murphy AM. Persistence of virus in lens for three years after prenatal rubella. Lancet 1967;2: $387-388$.

\title{
Emergency management of water supply pollution in a French teaching hospital
}

\author{
Solenn Guibourg $\mathrm{MD}^{1}$, Elodie Moalic PharmD², Raoul Baron $\mathrm{MD}^{1}$ and Philippe Saliou MD, $\mathrm{PhD}^{1,3,4}$ (1) \\ ${ }^{1}$ Infection Control Unit, Brest Teaching Hospital, Brest, France, ${ }^{2}$ Department of Microbiology, Brest Teaching Hospital, Brest, France, ${ }^{3}$ Université de Bretagne \\ Occidentale, Brest, France and ${ }^{4}$ Inserm U1078, Genetics, Functional Genomics and Biotechnology, Brest, France
}

Author for correspondence: Philippe Saliou, Service d'hygiène hospitalière, CHRU Morvan, 2 avenue Foch, 29200 Brest, France. E-mail: philippe.saliou@chu-brest.fr

Cite this article: Guibourg S, et al. (2019). Emergency management of water supply pollution in a French teaching hospital. Infection Control \& Hospital Epidemiology, 40: 1207-1209, https://doi.org/10.1017/ice.2019.223
To the Editor-Healthcare facilities are dependent on water supplies to deliver daily patient care. The water used for care and consumption in hospitals meets strict regulations for microbiological criteria 
Table 1. Impacts of Water Supply Interruption and Adopted Solutions

\begin{tabular}{|c|c|c|}
\hline Areas & Impacts & Solutions \\
\hline $\begin{array}{l}\text { Drinking } \\
\text { water }\end{array}$ & $\begin{array}{l}\text { Drinking at faucets and } \\
\text { fountains was forbidden. } \\
\text { Showering and bathing of } \\
\text { patients were forbidden. }\end{array}$ & $\begin{array}{l}\text { Bottled water was used for } \\
\text { drinking. } \\
\text { Use of wash cloths }\end{array}$ \\
\hline Food & $\begin{array}{l}\text { Food production was } \\
\text { stopped because } \\
\text { dishwashing was not } \\
\text { available. }\end{array}$ & $\begin{array}{l}\text { Food production limited to } \\
\text { simple items } \\
\text { Use of disposable plates } \\
\text { and utensils }\end{array}$ \\
\hline $\begin{array}{l}\text { Standard } \\
\text { cares }\end{array}$ & $\begin{array}{l}\text { Tap water was forbidden for } \\
\text { standard care. }\end{array}$ & Use of sterile water \\
\hline $\begin{array}{l}\text { Hand } \\
\text { hygiene }\end{array}$ & $\begin{array}{l}\text { Hand washing with soap and } \\
\text { tap water was forbidden. }\end{array}$ & $\begin{array}{l}\text { Use of alcohol-based hand } \\
\text { rub } \\
\text { Surgical hand antisepsis } \\
\text { performed using alcohol- } \\
\text { based hand rub }\end{array}$ \\
\hline $\begin{array}{l}\text { Dialysis } \\
\text { Sterilization } \\
\text { Endoscope } \\
\text { disinfection } \\
\text { Operating } \\
\text { room }\end{array}$ & $\begin{array}{l}\text { Saturation of system filters } \\
\text { and loss of water pression }\end{array}$ & $\begin{array}{l}\text { Use of } 0.2-\mu \mathrm{m} \text { filters } \\
\text { changed as often as } \\
\text { needed }\end{array}$ \\
\hline
\end{tabular}

(eg, absence of Escherichia coli, enterococci, and coliforms). ${ }^{1,2}$ In France, drinking water is provided by the city, which ensures water potability. ${ }^{3,4}$ In our hospital, which hosts $\sim 2,500$ beds at 2 main sites, this water can be directly used for standard care such as hand washing, bathing of patients, or reprocessing of medical equipment. It can also undergo treatment for use in intensive care units, operating rooms, and for hemodialysis, sterilization of surgical instruments, and endoscope disinfection.

Water supply interruptions remain very rare in French hospitals, but in November 2018, the entire water network of the Brest teaching hospital was polluted as a result of construction damage to the public water system. This event resulted in a major increase of the water turbidity from 0.20 to 8 NTU (nephelometric turbidity units) and caused emergency water supply interruption. We had no emergency water supply plan (EWSP), as recommended by the Center for Disease Control and Prevention, and we had to improvise our responses. ${ }^{5}$

Specific measures were taken by the Infection Control Unit in agreement with hospital leadership (Table 1). Drinking at faucets and fountains was forbidden and bottles of mineral water were distributed in units for patients and health workers. The use of tap water for standard care was stopped, and we asked health workers to use bottles of sterile water. Showering and bathing of patients were forbidden, as was hand washing with soap and tap water. We recommended the use of an alcohol-based hand rub as the preferred means for routine hand antisepsis in all clinical situations. Surgical hand antisepsis also had to be performed using alcohol-based hand rub. Many $0.2-\mu \mathrm{m}$ filters used for dialysis systems, in sterilization units, endoscopes disinfection areas, and especially in operating rooms were saturated. This resulted in a lack of pressure in dialysis systems, for example. We had to change filters regularly to maintain care. Food production was stopped and was limited to simple items. Disposable plates and utensils were used because dishwashing was not available.

The water supply was disrupted for 24 hours; it was solved by repairs on the public water system and a global purge of the hospital water system until the return of normal water turbidity. Water potability controls were implemented at different places in the hospital to represent the entire water system.

A few days after the episode, some potability controls for drinking fountains in different places in the hospital showed the presence of 1 pathogenic bacterium. This bacterium, the Enterobacteriaceae Lelliottia amnigena, was found in 4 different units and at remote locations within the hospital.

The presence of this bacterium was probably due to the water pollution, contamination of the drinking fountain system, and the diffusion of a biofilm into the hospital water network. Therefore, we had to make new controls for water potability of all the contaminated drinking fountains after disinfection. No digestive infections were reported following this accident, nor were adverse events due to the use of dialysis machines found during the episode.

This type of accident is unusual, but it must be anticipated. In hospitals, an action plan should be created to be fully prepared in case of such an accident. One of the most difficult decisions was when to authorize people to use the water from the hospital water system again. On one hand, it was difficult to stop the use of a water system for a long time while awaiting microbiological result because it disrupted the proper functioning of the hospital. On the other hand, there was a risk of endangering patients, staff, and visitors if we decided to use the water too soon. We finally decided to allow the use of water once the turbidity returned to normal (ie, $0.20 \mathrm{NTU}$ ).

Following this accident, the hospital decided to write an emergency water supply plan to deal with a new episode of water contamination.

Acknowledgments. The authors are grateful to Claudie Le Moigne and Monique Magnin for their contribution to the microbiological testing.

Financial support. No financial support was provided relevant to this article.

Conflicts of interest. All authors report no conflicts of interest relevant to this article

\section{References}

1. Direction générale de la santé (DGS). Décret n²001-1220 du 20 décembre 2001 relatif aux eaux destinées à la consommation humaine, à l'exclusion des eaux minérales. https://www.legifrance.gouv.fr/affichTexte.do?cidTexte= JORFTEXT000000215649. Accessed June 10, 2019.

2. Direction générale de la santé (DGS). Circulaire DHOS/E4/DGS/SD7A $n^{\circ} 2005-417$ du 9 septembre 2005 relative au guide technique sur l'eau dans les établissements de santé, Ministère de la santé et des solidarités. http:// nosobase.chu-lyon.fr/Reglementation/2005/Circulaire/090905.pdf. Accessed June 10, 2019.

3. Direction générale de la santé (DGS). Circulaire DGS/EA4 n²009-35 du 4 février 2009 relative à l'investigation des épidémies d'infection liées 
à l'ingestion d'eau de distribution publique. http://nosobase.chu-lyon.fr/ Reglementation/2009/Circulaire/040209.pdf. Accessed June 10, 2019.

4. Direction générale de la santé (DGS). Circulaire DGS/SD7A n²007-414 du 21 novembre 2007 relative à la prise en compte de la surveillance réalisée par le responsable de la production ou de la distribution d'eau dans le cadre du contrôle sanitaire des eaux destinées à la consommation humaine. http://
nosobase.chu-lyon.fr/Reglementation/2007/Circulaire/211107.pdf. Accessed June 10, 2019.

5. Centers for Disease Control and Prevention and American Water Works Association. Emergency water supply planning guide for hospitals and health care facilities. Atlanta: US Department of Health and Human Services; 2012.

\title{
RE: Preventability of hospital onset bacterermia and fungemia: A pilot study of potential healthcare-associated infection outcome measure, by Dantes et al (2019)
}

\author{
Anna M. Civitarese $\mathrm{MPH}^{1}$ (1), Eric Ruggieri $\mathrm{PhD}^{2}$ (1), J. Mattias Walz MD³ , Deborah Ann Mack RN CIC \\ Stephen O. Heard MD ${ }^{3}$, Michael Mitchell MD ${ }^{5}$, Craig M. Lilly MD ${ }^{6,7,8}$, Karen E. Landry BS $^{9}$ and \\ Richard T. Ellison III MD $^{4,6,10}$ (1) \\ ${ }^{1}$ Division of Preparedness, Response, Infectious Disease Epidemiology, and Emergency Medical Services, Rhode Island Department of Health, Providence, Rhode \\ Island, ${ }^{2}$ Department of Mathematics and Computer Science, College of the Holy Cross, Worcester, Massachusetts, ${ }^{3}$ Department of Anesthesiology and \\ Perioperative Medicine, University of Massachusetts Medical School Worcester, Massachusetts, ${ }^{4}$ Infection Control Department, UMass Memorial Medical Center, \\ Worcester, Massachusetts, ${ }^{5}$ Department of Pathology, University of Massachusetts Medical School, Worcester, Massachusetts, ${ }^{6}$ Department of Medicine, \\ University of Massachusetts Medical School, Worcester, Massachusetts, ${ }^{7}$ Graduate School of Biomedical Sciences, University of Massachusetts Medical School, \\ Worcester, Massachusetts, ${ }^{8}$ Department of Critical Care Operations, UMass Memorial Health Care, Worcester, Massachusetts, ${ }^{9}$ Fresenius Medical, Waltham, \\ Massachusetts and ${ }^{10}$ Department of Microbiology and Physiological Systems, University of Massachusetts Medical School, Worcester, Massachusetts
}

To the Editor-We read with great interest the article by Dantes et $\mathrm{al}^{1}$ on the preventability of hospital-onset bacteremias (HOBs) and the use of this metric as a quality outcome measure. In 2017, we also reported a retrospective analysis of the impact of quality improvement efforts on overall intensive care unit (ICU) HOBs over the course of 10 years at an academic medical center, during a period when the institution developed a virtual critical care department that utilized telemedicine technology and concurrently developed, implemented, and iteratively adapted multiple clinical practice guidelines across the ICUs of an academic medical center. ${ }^{2-4}$

In our study, which examined a total of 835 bacteremias across 7 ICUs, we observed a progressive and sustained $82.8 \%$ decrease in total annual bloodstream infections (BSIs), including an $85.0 \%$ decrease in primary BSIs and $81.4 \%$ decrease in secondary BSIs. ${ }^{2}$ Our analysis by pathogen also detected significant decreases in BSI rates for all pathogens, particularly highest for non-S. aureus staphylococci (0.300-fold per year) and Staphylococcus aureus(0.191-fold). Decreases in BSI rates were significant across all ICUs, with the exception of the cardiac surgery and coronary care unit. Potential confounders of decreased number of blood cultures drawn, length of ICU stay, APACHE IV scores, glucose levels, vital status, and number of stays were controlled for during regression analysis, and our results remained highly significant following this adjustment.

Thus, our findings indicate that institutions can prevent and markedly reduce the incidence of $\mathrm{HOBs}$, at least in the ICU setting. Moreover, BSIs represent a relatively objective end point where the primary identified limitations have been concerns with appropriate identification of blood culture contaminants and infections that arise from mucosal barrier injury., ${ }^{5,6}$ This focus

Cite this article: Civitarese AM, et al. (2019). RE: Preventability of hospital onset bacterermia and fungemia: A pilot study of potential healthcare-associated infection outcome measure, by Dantes et al (2019). Infection Control \& Hospital Epidemiology, 40: 1209-1210, https://doi.org/10.1017/ice.2019.193 contrasts with other hospital-acquired infection metrics such as catheter associated urinary tract infections, ventilator associated events, Clostridioides difficile infection, and central-line associated bloodstream infections, where multiple definition issues have been identified that can lead to both inaccurate estimations of infection rates and can potentially promote efforts to "game the system." 7,8

Acknowledgments. The authors thank the UMass Memorial Infection Control Preventionists who contributed over the last 10 years to compilation and maintenance of data used for this study.

Financial support. No financial support was provided relevant to this article.

Conflicts of interest. All authors report no conflicts of interest relevant to this article.

\section{References}

1. Dantes RB, Rock C, Milstone AM, et al. Preventability of hospital onset bacteremia and fungemia: a pilot study of a potential healthcare-associated infection outcome measure. Infect Control Hosp Epidemiol 2019;40:358-361.

2. Civitarese AM, Ruggieri E, Walz JM, et al. A 10-year review of total hospitalonset ICU bloodstream infections at an academic medical center. Chest 2017;151:1011-1017.

3. McCauley K, Irwin RS. Changing the work environment in ICUs to achieve patient-focused care: the time has come. Chest 2006;130:1571-1578.

4. Lilly CM, Cody S, Zhao H, et al. Hospital mortality, length of stay, and preventable complications among critically ill patients before and after tele-icu reengineering of critical care processes. JAMA 2011;305:2175-2183.

5. Freeman JT, Chen LF, Sexton DJ, Anderson DJ. Blood culture contamination with Enterococci and skin organisms: implications for surveillance definitions of primary bloodstream infections. Am J Infect Control 2011;39:436-438.

6. Steinberg JP, Coffin SE. Improving the central line-associated bloodstream infection surveillance definition: a work in progress. Infect Control Hosp Epidemiol 2013;34:777-779. 